\title{
Pengaruh Strategi Pembelajaran Inkuiri (SPI)Terhadap Kemampuan Pemahaman Konsep Siswa Kelas VIII SMP Negeri 18 Singkawang
}

\author{
Buyung $^{1)}$, Intan Kusumawati ${ }^{2)}$, Ressy Nirawati ${ }^{1)}$ \\ ${ }^{1)}$ Program Studi Pendidikan Matematika STKIP Singkawang, KALBAR, Indonesia \\ E-mail:21.buyung@gmail.com \\ 2) Program Studi Pendidikan Fisika STKIP Singkawang, KALBAR, Indonesia \\ E-mail:intankusumawati10@gmail.com \\ ${ }^{3)}$ Program Studi Pendidikan Matematika STKIP Singkawang, KALBAR, Indonesia \\ E-mail:resynirawaty@gmail.com
}

\begin{abstract}
Abstrak. Penelitian ini bertujuan untuk mengetahui aktivitas belajar siswa melalui SPI pada materi persamaan garis lurus, mengetahui pengaruh SPI terhadap peningkatan kemampuan pemahaman konsep siswa pada persamaan garis lurus, mengetahui respon siswa melalui SPI pada persamaan garis lurus. Penelitian ini diadakan pada siswa kelas VIII SMP Negeri 18 Singkawang, penelitian ini menggunakan pre eksperimental. Rancangan one grup pre-test post-test design. Rancangan ini pertama dilakukan pengukuran berupa pre-test kemudian diberikan perlakuan dengan jangka waktu tertentu, kemudian dilakukan pengukuran berupa post-test. Instrumen tes berupa tes essay yang telah diujicobakan, reliabilitas sebesar 0,45 dengan kriteria sedang. Berdasarkan perbandingan hasil tes awal (pre-test) sebelum perlakuan dan hasil tes akhir (post-test) setelah diberikan perlakuan dengan menggunakan SPI, ditemukan bahwa hasil post-test lebih tinggi dari hasil pre-test yaitu dari rata-rata 34,26 dan 63,04. Hasil perhitungan untuk lembar pengamatan aktivitas diperoleh persentase perilaku siswa aktif lebih besar dari pada siswa yang pasif $(83,95 \%>15,61 \%)$. Hasil analisis terhadap respon siswa diperoleh jumlah persentase siswa yang memilih SS (Sangat setuju) dan S (setuju) lebih besar dari siswa yang memilih R (Ragu), TS (tidak setuju) dan STS (sangat tidak setuju) yaitu $(84,71 \%>15,27 \%$ ). Respon siswa terhadap pembelajaran dengan SPI positif. Berdasarkan uraian yang telah dikemukakan, pembelajaran dengan menggunakan SPI pada materi persamaan garis lurus bagi siswa kelas VIII SMP Negeri 18 Singkawang terdapat peningkatan kemampuan pemahaman konsep, aktivitas baik dan respon siswa terhadap SPI adalah positif (senang).
\end{abstract}

Kata Kunci: Aktivitas, Pemahaman Konsep, Respon, SPI

\section{PENDAHULUAN}

Pendidikan merupakan upaya pengembangan potensi anak didik [5]. Pendidikan memegang peranan penting dalam mencapai kemajuan suatu negara. Sebagai negara berkembang, Indonesia berupaya meningkatkan kualitas pendidikan agar memiliki Sumber Daya Manusia (SDM) yang potensial untuk dapat berdaya saing tinggi. Dengan pendidikan yang matang, suatu bangsa akan memiliki SDM yang berkualitas. Oleh karena itu, kualitas pendidikan menjadi sangat penting dan perlu mendapat perhatian yang serius.

Satu diantara upaya meningkatkan SDM dalam bidang pendidikan, yaitu dengan peningkatan kemampuan siswa dalam pelajaran matematika.[1] menyatakan bahwa pengertian matematika tidak didefinisikan secara mudah, dan dapat mengingat berbagai fungsi dan peranan matematika terhadap bidang studi yang lain. Matematika dikenal sebagai ilmu yang sukar dipahami, tetapi banyak faktor yang dapat membantu memudahkan pemahaman matematika. Hal tersebut berupa cara menyampaikan materi, misalnya dengan menekankan pada keterlibatan siswa secara aktif dalam proses pembelajaran sehingga potensi siswa dapat berkembang dengan baik.

Matematika juga merupakan mata pelajaran yang penting untuk diajarkan kepada siswa disekolah. Hal ini dapat dilihat dari banyaknya aktivitas masyarakat yang cenderung berhubungan dengan matematika atau berhitung. Belajar matematika hendaknya tidak disamakan dengan ilmu yang lain karena belajar matematika tidak hanya mengetahui dan memahami ilmu yang terdapat di dalamnya, tetapi menuntut siswa berpikir secara kritis, logis, dan tepat. 


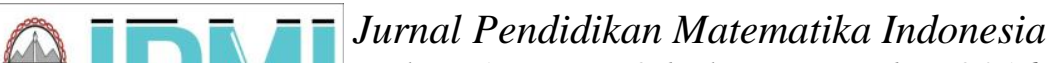 \\ Volum 1 Nomor 2 bulan September 2016. Halaman 87- 90 \\ p-ISSN: 2477-5967 e-ISSN: 2477-8443}

Pada pembelajaran matematika memuat materi persamaan garis lurus. Persamaan garis lurus adalah satu diantara materi yang diangap sulit untuk dipecahkan karena siswa belum mengerti dalam menyelesaikan soal yang berkaitan dengan gradien untuk menentukan persamaan garis, sehingga siswa menganggap matematika itu rumit dipelajari. Kondisi ini terjadi di kelas VIII SMP Negeri 18 Singkawang .

Berdasarkan data yang dikumpulkan dari hasil Ujian Nasional (UN) Provinsi Kalimantan Barat, khusus kota Singkawang tahun ajaran 2013/2014 SMP Negeri 18 Singkawang sub Rayon 04 berada di peringkat sembilan, hasil ujian matematikanya adalah 6,30 se-kota Singkawang. Adapun nilai rata-rata mata pelajaran matematika dengan jumlah peserta ujian sebanyak 16 orang adalah 5,14 nilai rata-rata terendah yang diperoleh siswa yaitu 2,75. Hal ini sangat jauh dari Kriteria Ketuntasan Minimal (KKM) yang menjadi ketetapan SMP Negeri 18 Singkawang, yaitu 75 (LPMP, 2013).

Dari hasil pra-riset pada 24 siswa kelas VIII SMP Negeri 18 Singkawang ditemukan bahwa terdapat $55 \%$ siswa yang mengalami kesulitan menyajikan konsep dalam berbagai bentuk representasi matematis, dan siswa yang menjawab benar sebesar $45 \%$ dari 24 siswa. Siswa mengalami kesulitan menggunakan dan memilih prosedur tertentu sebanyak $34 \%$ dan menjawab benar dan sebesar $66 \%$ dari 24 siswa. Sebanyak $55 \%$ siswa mengalami kesulitan mengklasifikasikan prosedur menurut sifat-sifat tertentu sesuai dengan konsep, dan siswa menjawab dengan benar sebesar $45 \%$ dari 24 siswa. Sebanyak 34\% siswa mengalami kesulitan mengklasifikasikan konsep ke pemecahan masalah dan menjawab dengan benar sebesar 66\% dari 24 siswa. Berdasarkan hasil pra-riset dengan menggunakan kuesioner atau angket pada SMP Negeri 18 Singkawang tersebut, maka dapat diketahui bahwa siswa masih mengalami kesulitan dalam pemahaman konsep pada materi persamaan garis lurus.

Hal ini diperkuat dari hasil wawancara terhadap guru matematika SMP Negeri 18 Singkawang mengenai aktivitas belajar siswa. aktivitas belajar adalah kegiatan yang dilakukan secara individu maupun rombongan, memiliki perencanaan belajar, strategi, media, tahapan tujuan tertentu, berhubungan dengan waktu dan tempat, serta aturan yang disepakati [3]. Proses belajar di dalam kelas masih kurang aktif dan cenderung pasif, sehingga aktivitas belajar siswa masih tergolong rendah. Kurang adanya kesadaran dan keinginan dari diri siswa untuk belajar, kurangnya dorongan untuk menumbuhkan minat belajar, serta kurangnya kemampuan pemahaman konsep siswa sehingga menjadi penyebab dari rendahnya aktivitas belajar siswa tersebut. Selain itu, ditemukan bahwa masih terdapat siswa yang cenderung melalaikan kewajibannya untuk mengerjakan tugas rumah (PR) dan siswa belum terlibat aktif dalam kegiatan pembelajaran matematika. Hal ini menunjukkan bahwa kurangnya respon dari siswa terhadap pembelajaran matematika.

Respon adalah perilaku yang muncul dikarenakan adanya rangsangan dari lingkungan. Apabila hal ini tidak ditindaklanjuti, maka dapat menyebabkan kompetensi dasar dan indikator pembelajaran tidak akan tercapai secara maksimal sesuai dengan tujuan yang diharapkan. Oleh karena itu, dibutuhkan suatu upaya untuk mengatasi hal tersebut melalui Strategi Pembelajaran yang dapat meningkatkan kemampuan pemahaman konsep siswa pada materi persamaan garis lurus, salah satu strategi pembelajaran yang dapat meningkatkan kemampuan pemahaman konsep matematis adalah inkuiri.

Inkuiri berasal dari bahasa inggris inquiry yang dapat diartikan sebagai proses bertanya dan mencari jawaban terhadap jawaban ilmiah yang diajukan [2]. pembelajaran inkuiri memiliki asalusul dalam praktek penyelidikan ilmiah dan berfokus pada proses pertanyaan, mengumpulkan dan menganalisis data, dan membangun penjelasan berbasis bukti dan argumen oleh kolaboratif terlibat dalam penyelidikan Hakkarainen et al, Krajcik \& Blumenfeld) dalam [7]. SPI adalah rangkaian kegiatan pembelajaran yang menekankan pada proses berpikir secara kritis dan analitis untuk mencari dan menemukan sendiri jawaban dari suatu masalah yang dihadapi, suatu cara, taktik atau keterampilan yang dikuasai 
guru untuk mengoptimalkan interaksi antara peserta didik dengan komponen lain menggunakan semua sumber belajar dalam upaya membelajarkan peserta didik. SPI menekankan pada proses mencari dan menemukan [4]. Keunggulan menggunakan SPI, yaitu siswa tidak hanya melakukan pembelajaran melalui proses penghafalan tanpa berpikir melainkan siswa dituntut untuk aktif dan kreatif pada kegiatan pembelajaran. SPI belum pernah diterapkan di SMP Negeri 18 Singkawang. Dengan demikian, SPI dapat dilakukan untuk mengatasi masalah pembelajaran siswa dalam upaya meningkatkan kemampuan pemahaman konsep siswa SMP Negeri 18 Singkawang , khususnya tentang persamaan garis lurus.

\section{METODE}

Jenis penelitian ini adalah jenis penelitian kuantitatif dengan metode eksperimen karena data yang diperoleh berhubungan dengan angka-angka yang dapat dihitung secara matematis dan sistematis. Penelitian ini menggunakan desain penelitian one grouppre-test post-test design [5]. Populasi dalam penelitian yang dilaksanakan ini adalah seluruh siswa kelas VIII SMP Negeri 18 Singkawang Selatan, yang berjumlah 24 siswa. Di sekolah tersebut hanya terdapat satu kelas VIII, maka sampel dalam penelitian ini sama dengan populasinya, yaitu berjumlah 24 siswa kelas VIII SMP Negeri 18 Singkawang Selatan. Dengan demikian, teknik pengambilan sampel yang digunakan dalam penelitian ini adalah sampling jenuh. Menurut [5], sampling jenuh adalah teknik penentuan sampel bila semua anggota populasi digunakan sebagai sampel.

Teknik pengumpulan data Pengukuran yang dimaksud dalam penelitian ini adalah dengan memberikan tes, yaitu tes awal (pre-test) dan tes akhir (post-test) kepada siswa mengenai persamaan garis lurus, tes yang digunakan dalam penelitian ini berbentuk uraian (essay) yang terdiri dari 3 butir soal. Teknik komunikasi tidak langsung digunakan untuk mengetahui respon dalam belajar dengan perlakuan, dalam hal ini, digunakan kuesioner/angket respon yang terdiri dari 12 pertanyaan berbentuk pilihan dengan tanda check list $(\sqrt{ })$. Observasi langsung untuk mengetahui aktivitas belajar siswa selama proses pembelajaran pada materi persamaan garis lurus.

Instrumen penelitian adalah lembar kuesioner atau angket dalam penelitian ini bertujuan untuk mengetahui respon siswa pada saat berlangsung pembelajaran dengan Strategi Pembelajaran Inkuiri (SPI) tentang persamaan garis lurus. Lembar tes digunakan untuk mengetahui kemampuan pemahaman konsep siswa tentang persamaan garis lurus. Lembar pengamatan aktivitas siswa digunakan untuk melihat keterlibatan siswa dalam proses pembelajaran.

Validitas bertujuan agar tes yang digunakan benar-benar untuk mengukur kemampuan siswa dalam menyelesaikan soal persamaan garis lurus, maka instrumen yang telah disusun diukur dengan validitas tes. Reliabilitas menunjukkan pada suatu pegertian bahwa suatu instrumen cukup dapat dipercaya untuk digunakan sebagai alat pengumpulan data karena instrumen tersebut sudah baik.

Berdasarkan hasil ujicoba pada 26 siswa kelas SMP Negeri 10 Singkawang. Nilai reliabilitas dengan menggunakan persamaan 1 , diperoleh sebesar 0,45. Dengan demikian, soal tes kemampuan pemahaman konsep siswa mempunyai reliabilitas dengan kriteria sedang. Teknis Analisis Data setelah data penelitian terkumpul dari hasil pengumpulan data melalui angket, tes, dan lembar observasi.

\section{HASIL DAN PEMBAHASAN}

HASIL

Hasil data pengamatan aktivitas siswa pada saat proses pembelajaran menggunakan SPI, untuk pertemuan pertama persentase tingkah laku siswa aktif pada kategori 1, 2, 3 adalah81,1\%, sedangkan untuk persentase tingkah laku siswa pasif pada kategori 4, 5, 6 adalah 18,06\%. Pertemuan kedua untuk persentase tingkah laku siswa aktif pada kategori 1, 2, 3 adalah $86,81 \%$, sedangkan persentase tingkah laku siswa pasif pada kategori 4, 5,6 adalah $13,17 \%$.

Jadi, aktivitas belajar siswa saat menggunakan SPI secara keseluruhan persentase untuk kategori siswa aktif adalah $83,95 \%$, sedangkan persentase siswa pasif secara keseluruhan adalah 15,61\%. 


\section{A - - - Jurnal Pendidikan Matematika Indonesia \\ Volum 1 Nomor 2 bulan September 2016. Halaman 87- 90 \\ p-ISSN: 2477-5967 e-ISSN: 2477-8443}

Berdasarkan Tabel perbedaan pre-test dan post-test tersebut dapat dibuat rangkuman yang ditampilkan pada Tabel 1 sebagai berikut.

TABEL 1

PERBEDAAN PRE-TEST DAN Post-Test

\begin{tabular}{ccc}
\hline Tes & Rata-rata $(\overline{\boldsymbol{x}})$ & Standar deviasi (SD) \\
\hline Pre-test & 34,26 & 11.78 \\
Post-test & 63,04 & 13,20 \\
\hline
\end{tabular}

Berdasarkan Tabel 1 tersebut diungkapkan bahwa nilai rata-rata hasil post-test lebih tinggi dibandingkan dengan nilai rata-rata hasil pre-test. Nilai rata-rata hasil pre-test adalah 34,26 dan nilai rata-rata hasil post-test adalah 63,04. Hal ini menunjukan bahwa pemahaman konsep meningkat setelah diberikan perlakuan dengan menggunakan strategi pembelajaran inkuiri. Pengujian normalitas jika $X_{\text {hitung }}^{2}<X_{\text {tabel, maka }}^{2}$ data berdistribusi normal, sedangkan jika $\mathrm{X}^{2}$ hitung $>$

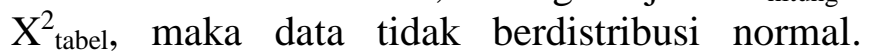
Diperoleh nilai $\mathrm{X}^{2}$ hitung $=0,8918$, sedangkan $\mathrm{X}^{2}$ tabel $=5,991$. Oleh karena ditemukan $X^{2}$ hitung $<X^{2}$ tabel maka datapost-test dalam penelitian ini berdistribusi normal.

Adapun uji hipotesis, $\mathrm{H}_{0}$ ditolak dan $\mathrm{H}_{\mathrm{a}}$ diterima pada taraf signifikan $\alpha=0,05$ artinya (SPI) dapat disimpulkan bahwa terdapat pengaruh Strategi Pembelajaran Inkuiri terhadap peningkatan kemampuan pemahaman konsep siswatentang persamaan garis lurus kelas VIII SMP Negeri 18 Singkawang Selatan.

Berdasarkan hasil jawaban siswa pada angket didapat hasil perhitungan yang memilih SS (Sangat Setuju) dan S (Setuju) sebesar 84,71\% dan yang memilih R (Ragu), TS (Tidak Setuju), dan STS (Sangat Tidak Setuju) sebesar 15,27\%.

PEMBAHASAN

Analisis data tentang aktivitas belajar siswa selama pembelajaran menggunakan Strategi Pembelajaran Inkuiri (SPI) diperoleh berdasarkan perhitungan lembar pengamatan yang dilakukan selama pembelajaran berlangsung, siswa aktif sebesar $83,95 \%$, sedangkan siswa pasif sebesar $15,61 \%$. Hal ini menunjukkan selama pembelajaran menggunakan SPI pada materi persamaan garis lurus aktivitas belajar siswa memiliki kriteria sangat baik.
Adapun hasil pengolahan data, diketahui adanya peningkatan pemahaman konsep siswa melalui SPI. Hal ini dapat dilihat dari perhitungan post-test, diperoleh nilai rata-rata 63,04yang naik sebesar 4,62 dari nilai rata-rata pre-test yaitu sebesar 34,26 . Untuk pengujian normalitas data pre-test diperoleh nilai $\mathrm{X}^{2}$ hitung $=1,3246$ sedangkan $\mathrm{X}_{\text {tabel }}^{2}=5,991$. Oleh karena itu ditemukan bahwa $\mathrm{X}_{\text {hitung }}^{2}<\mathrm{X}_{\text {tabel, maka data berdistribusi normal }}^{2}$ dan pengujian normalitas data post-test diperoleh nilai $X^{2}$ hitung $=0,8918$, sedangkan $X_{\text {tabel }}^{2}=5,991$. Berdasarkan pengujian normalitas, didapatkan hasil bahwa data berdistribusi normal, maka selanjutnya pengujian hipotesis menggunakan uji-t dan diperoleh bahwa $t_{\text {hitung }}>t_{\text {tabel }}$, yaitu $9,5439>2,069$. Dengan demikian $\mathrm{H}_{0}$ ditolak dan $\mathrm{H}_{\mathrm{a}}$ diterima pada taraf signifikan $\alpha=0,05$ sehingga dapat disimpulkan bahwa terdapat pengaruh SPI terhadap peningkatan kemampuan pemahaman konsep siswa terhadap persaman garis lurus. Hal ini membuktikan bahwa SPI dapat meningkatkan kemampuan pemahaman konsep siswa pada kelas VIII SMP Negeri 18 Singkawang Selatan. Hal ini diperkuat oleh [6], bahwa penggunaan SPI dapat meningkatkan pembelajaran matematika.

Faktor yang menyebabkan meningkatnya pemahaman siswa melalui SPI adalah rangkaian kegiatan pembelajaran yang menekankan pada proses berpikir secara kritis dan analitis untuk mencari dan menemukan sendiri jawaban dari suatu permasalahan yang dipertanyakan. Proses berpikir itu sendiri biasanya dilakukan melalui tanya jawab antara guru dan siswa. Pembelajaran dengan SPI mempunyai ciri utama. Pertama, SPI menekankan kepada aktivitas belajar siswa secara maksimal untuk mencari dan menemukan, artinya SPI menempatkan siswa sebagai subjek belajar. Kedua, seluruh aktivitas belajar siswa yang dilakukan diarahkan untuk mencari dan menemukan jawaban sendiri dari suatu pertanyaan, sehingga diharapkan dapat menumbuhkan sikap percaya diri. Ketiga, tujuan dari penggunaan SPI adalah mengembangkan kemampuan berpikir secara sistematis, logis, dan kritis, atau mengembangkan kemampuan intelektual sebagai bagian dari proses mental [4]. 
Setelah proses belajar dengan strategi pembelajaran inkuiri selesai, kepada siswa diberikan angket respon untuk mengetahui tanggapan siswa selama proses pembelajaran berlangsung, siswa hanya memilih salah satu tanggapan yang telah disediakan. Dari data yang diolah, didapat persentase siswa yang memilih SS (Sangat Setuju) dan S (Setuju) lebih besar dari pada siswa yang memilih R (Ragu), TS (Tidak Setuju) dan STS (Sangat Tidak Setuju). Dengan demikian, dapat disimpulkan bahwa respon siswa tergolong positif berdasarkan data angket respon dengan menggunakan strategi pembelajaran inkuiri pada materi persamaan garis lurus.

Dari uraian tersebut, pembelajaran dengan menggunakan Strategi Pembelajaran Inkuiri (SPI) pada materi persamaan garis lurus dinyatakan dapat meningkatkan kemampuan pemahaman konsep siswa dan membantu siswa lebih aktif dalam kegiatan pembelajaran, sehingga siswa merespon dengan baik kegiatan pembelajaran.

\section{KESIMPULAN DAN SARAN}

\section{KESIMPULAN}

Berdasarkan hasil pengelolahan data penelitian yang dilakukan, secara umum dapat disimpulkan bahwa aktivitas belajar siswa melalui SPI pada materi persamaan garis lurus di kelas VIII SMP Negeri 18 Singkawang Selatan memiliki kriteria sangat baik, pengaruh SPI terhadap peningkatan kemampuan pemahaman konsep siswa pada materi persamaan garis lurus adalah terdapat perbedaan yang signifikan antara pemahaman konsep sebelum dan sesudah diberikan perlakuan. Respon belajar siswa melalui SPI pada materi persamaan garis lurus di kelas VIII SMP Negeri 18 Singkawang Selatan adalah positif.

SARAN

Strategi Pembelajaran Inkuiri (SPI) sebagai salah satu alternatif pembelajaran yang dilaksanakan di sekolah, sebab SPI dapat meningkatkan aktivitas siswa. Sebaiknya SPI diterapkan di sekolah lain untuk mengetahui respon siswa di sekolah yang berbeda. Sebaiknya kemampuan pemahaman konsep siswa yang diajarkan dengan Strategi Pembelajaran Inkuiri (SPI) diajarkan pada materi lainnya juga, selain persamaan garis lurus. Sebaiknya menjelaskan kepada siswa agar tidak takut membuat kesalahan dalam kegiatan pembelajaran menggunakan SPI, sebab siswa cenderung takut untuk mencoba.

\section{DAFTAR PUSTAKA}

[1] Hamzah, Ali dan Muhlisrarini. (2014). Perencanaan Dan Strategi Pembelajaran Matematika. Jakarta: kharisma putra utama offset.

[2] Kasmad, M. (2012). Model-model Pembelajaran Berbasis PAIKEM. Tangerang: PT PUSTAKA MANDIRI

[3] Kasmadi dkk. (2013). Panduan Modern Penelitian Kuantitatif. Bandung: ALFABETA.

[4] Sanjaya,W. (2013). Strategi Pembelajaran Berorientasi Standar Proses Pendidikan. Jakarta: Fajar interpratama mandiri.

[5] Sugiyono. (2013). Metode Penelitian Pendidikan Pendekatan Kuantitatif,Kualitatif, Dan R\&D. Bandung: ALFABET, cv

[6] Sutarsih. (2012). Penggunaan Strategi Pembelajaran Inkuiri Untuk Peningkatan Pembelajaran Mata Pelajaran Matematika Di Kelas SD.

[7] Song, Y \& Looi, C. 2012. Linking Teacher Beliefs, Practices And Student Inquiry-Based Learning In A CSCL Environment: A Tale Of Two Teachers. Computer-Supported Collaborative Learning (2012) 7:129-159. DOI 10.1007/S11412-011-9133-9. 